University of Nebraska - Lincoln

DigitalCommons@University of Nebraska - Lincoln

Faculty Publications from the Harold W. Manter Laboratory of Parasitology

2-1997

\title{
Myxobolus mississippiensis n. sp. (Myxosporea) from Gills of Lepomis macrochirus in Mississippi
}

David K. Cone

St. Mary's University, david.cone@smu.ca

Robin M. Overstreet

Gulf Coast Research Laboratory, robin.overstreet@usm.edu

Follow this and additional works at: https://digitalcommons.unl.edu/parasitologyfacpubs

Part of the Parasitology Commons

Cone, David K. and Overstreet, Robin M., "Myxobolus mississippiensis n. sp. (Myxosporea) from Gills of Lepomis macrochirus in Mississippi" (1997). Faculty Publications from the Harold W. Manter Laboratory of Parasitology. 445.

https://digitalcommons.unl.edu/parasitologyfacpubs/445

This Article is brought to you for free and open access by the Parasitology, Harold W. Manter Laboratory of at DigitalCommons@University of Nebraska - Lincoln. It has been accepted for inclusion in Faculty Publications from the Harold W. Manter Laboratory of Parasitology by an authorized administrator of DigitalCommons@University of Nebraska - Lincoln. 


\title{
MYXOBOLUS MISSISSIPPIENSIS N. SP. (MYXOSPOREA) FROM GILLS OF LEPOMIS MACROCHIRUS IN MISSISSIPPI
}

\author{
David K. Cone and Robin Overstreet ${ }^{\star}$ \\ Department of Biology, Saint Mary's University, Halifax, Nova Scotia, Canada B3H 3C3
}

\begin{abstract}
Myxobolus mississippiensis n. sp. is described from gill lamellae of the bluegill (Lepomis macrochirus) inhabiting the Pascagoula River System, Mississippi. Fresh spores measure 16.4-18.7 $\mu \mathrm{m}$ long, 3.9-6.2 $\mu \mathrm{m}$ wide, and 4.7-6.2 $\mu \mathrm{m}$ thick. Spore width to length ratio is $1: 3.2$. Polar capsules are 5.5-7.8 $\mu \mathrm{m}$ long and $1.5-2.3 \mu \mathrm{m}$ wide, with $9-10$ filament coils that when extruded measure $42.1 \pm 4.2 \mu \mathrm{m}$. This parasite is unique among known species of Myxobolus in having spores that are lenticular in frontal view.
\end{abstract}

During examination of centrarchid fishes of Mississippi for myxosporean parasites, we found a previously undescribed species of Myxobolus Bütschli, 1882 (Myxosporea) parasitizing gills of the bluegill. This report describes that material and discusses its possible relation to species in Henneguya Thélohan, 1892.

\section{MATERIALS AND METHODS}

Five adult specimens of the bluegill (Lepomis macrochirus) were collected in September 1994 by seining in the Pascagoula River and joining bayous, near Vancleave, Mississippi. Fish were fixed whole in $10 \%$ buffered formalin and rinsed overnight in tap water prior to necropsy, which included microscopical examination of all organs. Sample tissues were dehydrated in a graded ethanol series, cleared in xylene, and embedded in Paraplast. Histological sections ( $7 \mu \mathrm{m}$ thick) were stained with hematoxylin and eosin. Fresh spores were obtained from an additional 4 of 10 bluegills collected 19 February 1996 from the Pascagoula River. Those spores from 3 pseudocysts were mixed together in a wet mount and then measured and photographed. Air-dried smears of fresh spores were stained with Giemsa. Other fresh spores were mounted in India ink or stained with Lugol's iodine solution. Spore measurements are presented in micrometers as a mean \pm SD followed in parentheses by the range.

\section{DESCRIPTION \\ Myxobolus mississippiensis n. sp.

$$
\text { (Figs. 1-12) }
$$

Plasmodia occurring as subspherical pseudocysts, up to $300 \mu \mathrm{m}$ long; ectoplasm thin; endoplasm poorly defined, containing randomly arranged fully developed spores. Spores lenticular in frontal view; anterior end usually more blunt than posterior end (see figures); posterior extremity tapered, rounded, or pointed; posterior tip frequently bending slightly away from sutural plane; aberrant spore specimens $(0.5 \%$ of spores in a pseudocyst) often with pair of thin posterior extensions of spore valves; extensions $1-16$ long (Fig. 12). Fresh spores $(n=15)$ $17.7 \pm 0.6(16.4-18.7)$ long, $5.2 \pm 0.7$ (3.9-6.2) wide, $5.4 \pm 0.8(4.7-$ $6.2)$ thick, without mucous envelope; fixed spores $(n=15)$ from different specimen $16.8 \pm 0.8$ (16-18) long, $5.2 \pm 0.3$ (5.0-5.3) wide, 5 thick. Spore width to length ratio in fresh spores $1: 3.3 \pm 0.5$ (1:2.8 4.4 ), in fixed spores $1: 3.2 \pm 0.2(1: 2.9-3.5)$. Spore valves smooth, de-

Received 1 April 1996; revised 12 August 1996; accepted 12 August 1996.

* Gulf Coast Research Laboratory, P.O. Box 7000, Ocean Springs, Mississippi 39566. void of sutural ridge folds. Polar capsules narrowly pyriform, converging anteriorly but not crossing, $7.2 \pm 0.59$ (5.5-7.8) long $(6.3 \pm 0.6$ [5.5-7.0] long in fixed specimens), with ratio of length to spore length $1: 2.4 \pm 0.2(1: 2.2-2.8), 1.6 \pm 0.2(1.5-2.3)$ wide $(1.5 \pm 0.2$ [1.0-2.0] wide in fixed specimens), typically equal in length but frequently with 1 capsule 1-2 shorter than other, with intercapsular appendix absent. Polar filament exhibiting 9-10 coils arranged perpendicular to long axis of capsule, $42.1 \pm 4.2$ (35-46) long when extruded. Sporoplasm single, occupying almost $2 / 3$ of spore length, sometimes containing prominent ( $2 \mu \mathrm{m}$ wide) roundish-shaped vacuole. Iodinophilous vacuole absent.

\section{Taxonomic summary}

Type host: Lepomis macrochirus Rafinesque, 1819, bluegill (Centrarchidae).

Site of infection: Capillary bed of secondary gill lamellae. Other organs not infected.

Type locality: Bluff Creek; also in nearby Swift Bayou and associated Pascagoula River, Jackson County, Mississippi.

Type specimens: Syntypes on Giemsa-stained, air-dried smear in U.S National Parasite Collection no. 86817, Beltsville, Maryland.

Prevalence of infection: Five of $11(45 \%)$.

Etymology: The species is named for the type locality.

\section{DISCUSSION}

Four-hundred sixty-six nominal species of Myxobolus have been described from aquatic vertebrates, the majority of which are from fishes (Cone et al., 1990; Maeno et al., 1990; Landsberg and Lom, 1991; Segovia Salinas et al., 1991; Fomena et al., 1993; Lom and Dyková, 1994; Masoumian et al., 1994). Of these, 110 species are known from freshwater fishes of North America (Cone and Raesly, 1995; Cone et al., 1996). Myxobolus mississippiensis $\mathrm{n}$. sp. is unique in its lenticular frontal view. Spores of all other known species of Myxobolus are either circular, ellipsoidal, pyriform, or narrowly pyriform in frontal view (Shulman, 1966; Lom and Dyková, 1992).

Three species of Myxobolus in addition to M. mississippiensis have been reported from Lepomis macrochirus: Myxobolus osburni Herrick, 1936, Myxobolus cartilaginis Hoffman, Putz, and Dunbar, 1965, and Myxobolus corneus Cone, Horner, and Hoffman, 1990 (see Herrick, 1936; Otto and Jahn, 1943; Hoffman et al., 1965; Cone et al., 1990). Spores of these species can be easily distinguished from those of $M$. mississippiensis by their circular or suboval frontal aspect.

FIGURES 1-10. Myxobolus mississippiensis n. sp. parasitizing Lepomis macrochirus from the Pascagoula River system, Mississippi. 1. Small oval plasmodium from fresh tissue smear, unstained. Scale bar $30 \mu \mathrm{m}$. 2. Histological section (H\&E stained) through a plasmodium revealing its location within secondary lamellae. Scale bar $20 \mu \mathrm{m}$. 3-5. Photomicrographs of series of developed spores in frontal view. 6. Side view. Scale bar $10 \mu \mathrm{m}$. 7-10. Series of spores with atypical development of posterior extremity. 

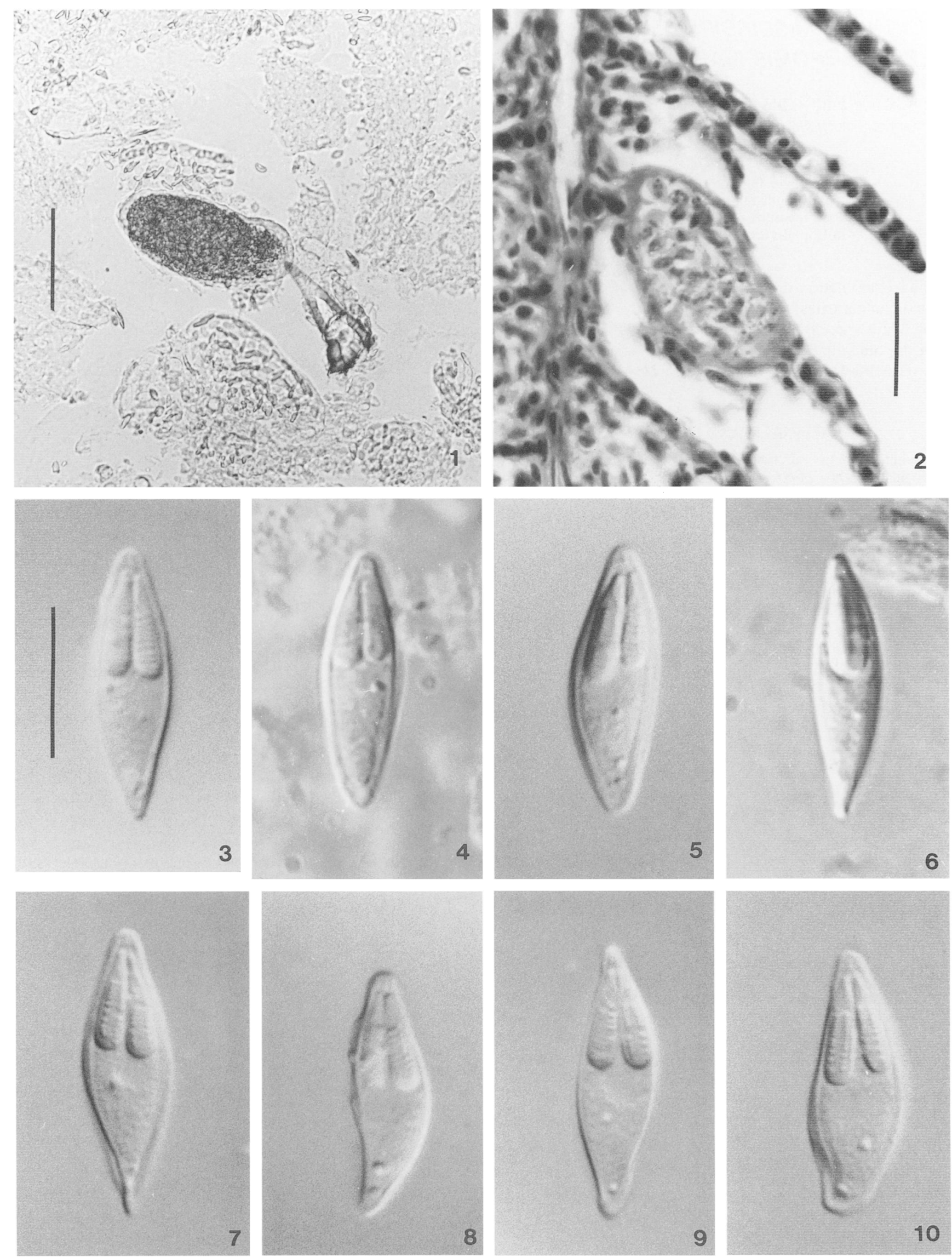


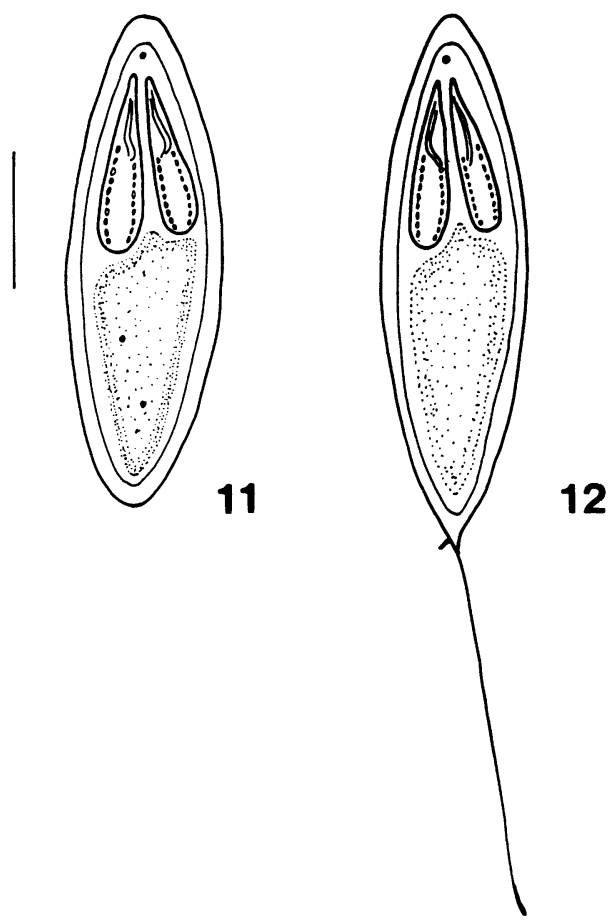

FIGURES 11, 12. Line drawings of Myxobolus mississippiensis n. sp. in frontal view. 11. Typical spore. 12. Abnormal spore with posterior extension of the valve. Scale bar $5 \mu \mathrm{m}$.

We have assigned M. mississippiensis to Myxobolus because it complies with the revised definition of the genus, characterized by having species with 2 polar capsules in the apex of the spore, both of which are set in the sutural plane (Lom and Noble, 1984; Lom and Dyková, 1992). The unique lenticular shape of spores of $M$. mississippiensis expresses a similarity to that for spores of species in Henneguya. The valves differ by normally not extending as posterior filaments. Perhaps the occasional filamentous spore of $M$. mississippiensis and the filaments on spores of species of Henneguya are homoplasies resulting from convergent evolution. If so, such an event among species of Myxobolus is rare. On the other hand, those spores of $M$. mississippiensis with short filament-like posterior extensions of the valves, similar in appearance to the spores with normal filaments on species of Henneguya, provide the more likely explanation that $M$. mississippiensis is related to species of Henneguya. That relationship suggested by morphological features similar to those of some species of Henneguya would support rRNA sequence studies by Smothers et al. (1994) that suggest Henneguya and Myxobolus are related. They showed that certain species of Myxobolus apparently had closer phylogenetic ties with species of Henneguya than with other species of Myxobolus. The finding of abnormal spore extensions is not unique for M. mississippiensis. Some spores of at least one other species, Myxobolus muelleri Mitchell, 1989 from freshwater fishes in Montana, also exhibited abnormal posterior filaments (Mitchell, 1989).

\section{ACKNOWLEDGMENTS}

The authors thank Bill Font for arranging the initial collection of fishes that led us to find the parasite. The work was supported in part by an NSERC operating grant awarded to D.K.C., U.S. Department of Commerce, National Marine Fisheries Service Award no. NA26F 10085-01 and International Paper.

\section{LITERATURE CITED}

Cone, D. K., R. W. Horner, And G. L. Hoffman. 1990. Description of Myxobolus corneus (Myxosporea): A new species from the eyes of bluegills from Illinois. Journal of Aquatic Animal Health 2: 132134.

- AND R. L. RAESLY. 1995. Redescription of Myxobolus rhinichthidis (Myxosporea) parasitizing Rhinichthys cataractae, with a revised taxonomic list of species of Myxobolus known from North American freshwater fishes. Canadian Journal of Fisheries and Aquatic Sciences 52: 7-12.

, R. G. Stickel, G. W. Eck, and P. M. Muzzall. 1996. Myx obolus cognati n. sp. (Myxosporea) from the opercular integument of Cottus cognatus (Cottidae) in Lake Michigan. Journal of Parasitology 82: 137-139.

Fomena, A., A. MARgues, And G. BouIX. 1993. Myxosporidea (Myxozoa) of Oreochromis noliticus (Linnaeus, 1757) (Teleost Cichlidae) in fish-farming pools at Melen (Yaounde, Cameroon, Central Africa). Journal of African Zoology 107: 45-56.

Herrick, J. A. 1936. Two new species of Myxobolus from fishes of Lake Erie. Transactions of the American Microscopical Society 55: 194-198.

Hoffman, G. L., R. R. Putz, and C. E. Dunbar. 1965. Studies on Myxosoma cartilaginis sp. n. (Protozoa: Myxosporidia) of centrarchid fish and a synopsis of the Myxosoma of North American freshwater fishes. Journal of Protozoology 12: 319-332.

LANDSBerg, J. H., AND J. Lom. 1991. Taxonomy of the genera of the Myxobolus/Myxosoma group (Myxobolidae: Myxosporea), current listing of species and revision of synonyms. Systematic Parasitology 18: 165-186.

Lom, J., AND I. DykovÁ. 1992. Protozoan parasites of fishes. Developments in Aquaculture and Fisheries Science 26: 1-315. , AND - 1994. Studies on protozoan parasites of Australian fishes. III. Species of the genus Myxobolus Bütschli, 1882. European Journal of Protistology 25: 431-439.

- AND E. R. NoBle. 1984. Revised classification of the class Myxosporea Bütschli, 1881. Folia Parasitologica (Praha) 31: 193205.

Maeno, Y., M. Sorimachi, K. Ogawa, and S. Egusa. 1990. Myxobolus spinacurvatura $\mathrm{n}$. sp. (Myxosporea: Bivalvulida) parasitic in deformed mullet, Mugil cephalus. Fish Pathology 25: 37-41.

Masoumian, M., F. BASKA, AND K. Molnar. 1994. Description of $M y x$ obolus karuni sp. n. and Myxobolus persicus sp. n. (Myxosporea, Myxozoa) from Barbus grypus of the River Karun, Iran. Parasitologia Hungarica 27: 21-26.

MitCHELL, L.C. 1989. Myxobolid parasites (Myxozoa: Myxobolidae) infecting fishes of western Montana, with notes on histopathology, seasonality, and intraspecific variation. Canadian Journal of Zoology 67: 1915-1922.

OTTO, G. R., AND T. L. JAHN. 1943. Internal myxosporidian infections of some fishes of the Okoboji Region. Proceedings of the Iowa Academy of Science 50: 323-335.

Segovia Salinas, F, F. Jimenez-Guzman, L. Galaviz-Silva, and E. RAMIREZ-BON. 1991. Myxobolus nuevoleonsis n. sp. (Myxozoa: Myxobolidae) parasite of fishes Poecilia mexicana and P. reticulata from Rio de la Silla near Monterray, Nuevo Leon, Mexico. Revista Latinoamericana de Microbiologia 33: 265-269.

Shulman, S. S. 1966. Myxosporidia [fauna] of the USSR. Nauka Publishers, Moscow-Leningrad. Translated version published for the United States Department of the Interior and National Science Foundation, Amerind Publishing Co. Pvt. Ltd., New Delhi, 1988, $631 \mathrm{p}$.

Smothers, J. F., C. D. Von Dohlen, L. H. Smith, JR., and R. D. Spall. 1994. Molecular evidence that the myxozoan protists are metazoans. Science 265: 1719-1721. 